\title{
The ISDS Mechanism and Standards of Protection in the Investment Treaty
}

\author{
Pandu Rizky Putra Pratama \\ Universitas Padjadjaran, Indonesia \\ pratamapandurizky@gmail.com
}

\author{
Prita Amalia \\ Universitas Padjadjaran, Indonesia \\ prita.amalia@unpad.ac.id
}

\begin{abstract}
International investment activities require legal certainty for investors. While the host country also needs legal certainty related to state sovereignty, legal protection is needed for investors and the host country to realize legal certainty in investment activities. Countries in the world entered into investment agreements to provide legal protection for investment activities. In investment agreements, generally, there are requirements to comply with the national law of the host country to get protection from investment agreements. This study aims to review the implications of not fulfilling the obligations in the investment agreement to apply the benefits contained therein, specifically regarding ISDS mechanism and protection standards. This study finds that the impact of the non-fulfillment of these obligations on the ISDS mechanism depends on the admission clause specified in the Bilateral Investment Treaty (BIT). On standards of protection, it refers to general principles of international law and arbitration decisions, investments that violate these obligations do not receive international legal protection. This research suggests the Indonesian Government tighten the admission clause in the BIT to prevent investors from using the ISDS mechanism in the BIT and to specify the impact of violating obligations to comply with the national laws of the host country.
\end{abstract}

KEYWORDS: International Investment Law, Standards of Protection, Bilateral Investment Treaty.

cC (1) (2) Copyright ${ }^{\odot} 2020$ by Author(s)

This work is licensed under a Creative Commons Attribution-ShareAlike 4.0 International License. All writings published in this journal are personal views of the authors and do not represent the views of this journal and the author's affiliated institutions.

\section{HOW TO CITE:}

Pratama, Pandu Rizky Putra \& Amalia, Prita. "The ISDS Mechanism and Standards of Protection in the Investment Treaty" (2020) 7:2 Lentera Hukum 153-170

Submitted: April 14, 2020 Revised: June 30, 2020 Accepted: July 27, 2020 


\section{INTRODUCTION}

Foreign investment activities have a crucial role in order to meet national needs in Indonesia. One of the challenges to Indonesia's infrastructure development is the shortage of funding for the project, as part of the preparation process. ${ }^{1}$ The infrastructure development project needs a relatively high level of funding and needs to be sustainable. Investment Coordinating Board's data stated that the realization of foreign investment in Indonesia in 2020 from January 2020 to March 2020 reached a total of 210,7 trillion rupiah. The entry of foreign investment in a country (the host country) is very influential, especially in factors such as technology transfer, employment and capital transfer. ${ }^{2}$ The main reason that encourages countries to carry out international investment activities is the need for sources of capital for investment because the government and private parties need funds to finance development projects that are carried out by importing them including expertise, management, and technology, as well as services, goods, and equipment. Despite the debates characterizing foreign investment as an infringement upon state sovereignty, international trade and investment are unavoidable in a largely liberalized global economy. As high funding requirements for development cannot be entirely mobilized from state budgets, including that of Indonesia, foreign investment and trade are unavoidable but necessary. ${ }^{3}$

The legal factor can attract investors to invest in a country because various legal provisions related to investment are necessary to adjust to various multilateral, regional, and bilateral agreements that are followed by the Indonesian government. ${ }^{4}$ In this issue, investors need legal certainty so that the capital they have invested can be protected. The host state also requires legal certainty related to the sovereignty of the country. A state's right to enact laws and develop public policy is a right established by state sovereignty, which dates back to the treaty of Westphalia in 1684 and is still firmly observed today. ${ }^{5}$ Therefore, legal protection has a very crucial role in the sustainability of international investment activities.

Huala Adolf stated that in principle there are four main areas of international law governing this investment. First, international law governing the protection of investors and their property. Second, international law governing bilateral relations or transactions between two countries, also known as Bilateral Investment Treaty (BIT). Agreements like this are made in many developed and developing countries. Third, international law

1 Prita Amalia \& Danrivanto Budhijanto, The Force of Strategic Infrastructures: The Role of PublicPrivate-Partnership to Strengthen Sustainable Developments in Indonesia, (2018) 12:4 Central European Journal of International and Security Studies, at 549.

2 An An Chandrawulan. Peran dan Dampak Perusahaan Multinasional dalam Pembangunan Ekonomi Indonesia Melalui Penanaman Modal dan Perdagangan Internasional, Dalam Buku Penemuan Hukum Nasional dan Internasional (Dalam Rangka Purnabakti Prof. Yudha Bakti). (Bandung: Fikahati Aneska, 2012) at 18.

3 Wachid Aditya Ansory, et al, The Application of the MFN Principle to the 'Over Top' Companies in Investment Activities of Indonesia, (2019) 6:2 Lentera Hukum, at 190.

4 Sentosa Sembiring. Hukum Investasi Pembahasan Dilengkapi Dengan Undang - Undang No. 25 Tahun 2007 Tentang Penanaman Modal. (Bandung: Nuansa Aulia, 2007) at 49.

5 H. H. Koh, Why Do Nations Obey International Law?, (1997) Faculty Scholarship Series Paper 2101, Yale Law School Legal Scholarship Repository, at 40. 
governing investment efforts in a particular region. This effort arose as a reaction of dissatisfaction with international law protecting investors and their property. Included in this case is the principle of compensation payments when the nationalization of foreign investment occurs. Fourth, the development of new international legal rules governs investment efforts related to international trade (The Trade-Related Investment Measures or TRIMS within the WTO). ${ }^{6}$

The second field BIT is an investment agreement signed by the two countries and binding rights and obligations to facilitate the investment in each country. This BIT agreement developed based on bargaining, namely the promise of capital protection in exchange for the prospect of more significant capital in the future. ${ }^{7}$ BIT solely regulates investment relations between two countries to manage investments made between the parties. It is recalling that investment treaties were historically signed due to concerns of investors from developed countries about being exposed to unjust treatment by developing-country governments. In this case, the main objective of a BIT is to increase the protection of "reciprocal encouragement" of investment in each company's territory in each investor's territory by creating transparent and non-discriminatory investment practices between countries and investors. It aims to support the development of international legal standards that are in line with these goals.

The BIT agreement has investment protection standards that must be carried out by the host country, such as: (a) fair and equitable treatment or no discrimination from all types of investment both foreign and domestic; (b) full protection and security contain the state's obligation to provide compensation for losses suffered by corporations due to war, armed conflict, revolution, state emergencies, riots, or rebellion. Usually, this protection is in the form of compensation or recovery; (c) protection from expropriation or nationalization and requires compensation; and $(d)$ the Investor-State Dispute Settlement (ISDS) mechanism. ${ }^{8}$

Investment activities require protection of investments made by foreign investors for countries that are sovereign as subjects of international law and a part of the international community and are an obligation that is inherent to each country following common practice in association and economic relations between countries to guarantee and create investment security. ${ }^{9}$ Therefore, the inclusion standards of protection in the BIT is solely aimed at protecting the investment made by the investor. Standards of protection in the BIT in general, namely full protection and security, fair and equitable treatment, most-favored, and so forth.

In addition to setting forth substantive obligations undertaken by the State parties, the vast majority of BITs and other international investment agreements contain

6 Huala Adol. Perjanjian Penanaman Modal dalam Hukum Perdagangan Internasional (WTO). (Bandung: CV Keni Media Cetakan Kedua, 2011) at 2-3.

7 Jeswald W. Salauce \& Nicholas P. Sullivan, Do BITS Really Work?: An Evaluation Of Bilateral Investment Treaties And Their Grand Bargain, (2005) 46 Harvard International Law Journal 67, at 95.

8 Rachmi Hertanti \& Rika Febriani. BIT (Bits) "Negara VS Korporasi. (Jakarta: Indonesia For Global Justice, 2014) at 5.

9 Fredy Roeroe, et al. Batam Komitmen Setengah Hati. (Jakarta: Aksara Karunia, 2003) at 108. 
provisions for the settlement of disputes between investors and the host State through international arbitration. ${ }^{10}$ ISDS itself is a mechanism that is included in various trade and investment agreements to resolve disputes between countries and investors. The settlement of these disputes depends on arbitration, and not through the public court. The ISDS mechanism is a form of protection afforded by BIT to investment. The ISDS mechanism in BIT is also a form of agreement from the state in dealing with a dispute with investors coming from a state party from BIT. These dispute settlement provisions accompany traditional State-State dispute settlement mechanisms, also commonly included in the investment agreement. Notwithstanding increasing criticism of ISDS, the vast majority of treaties continue to permit investors to bring direct international claims against host States.

In general BIT, there is an admission clause that requires an investment made by an investor to comply with the law of the host country in order to obtain legal protection or benefits from the BIT. The admission clause is essential in the BIT because it is legalized and declares it legally permits foreign investment to carry out business and investment activities in other countries' territories. ${ }^{l l}$ Problems arise when an investor sues the host country for violations in the BIT, but at the same time, there is an act of violation of national law committed by the investor in carrying out his investment, thus violating the admission clause which requires that the investment made by the investor must comply with the law of the host country. The admission clause's primary purpose is to prevent the BIT agreement from protecting investments that should not be protected, especially since the investments are made illegal. ${ }^{12}$

The main discussion of this article is legal issues regarding the legal protection given to investors in investment disputes where the investment violates the admission clause in BIT that requires investment to be carried out following the laws of the host country. Two problem statements will be discussed in this study. First, what is the ISDS mechanism in BIT in disputes arising by investors that violate the national law of the host country? Second, can the standards of protection in BIT protect investors who violate the host country's national law? Furthermore, this article will discuss these issues in two parts. The first part will discuss the provisions of the admission clause in the BIT that relating to the legality of investment. The second part concentrates on the position of ISDS mechanism in an investment dispute, in which there is a violation of the national law of the host country by investors. The last part will be elaborating on the implementation of standards of protection on the investment that violates the host country's national law.

10 United Nations Conference on Trade and Development, Investor-State Dispute Settlement, (UNCTAD Series on Issues in International Investment Agreements II, 2014) at 18.

Il Kusnowibowo. Hukum Investasi Internasional. (Bandung: Pustaka Reka Cipta, 2019) at 91.

12 Rahim Moloo \& Alex Khachaturian, The Compliance With The Law Requirement In International Investment Law, (2011) 34:6 Fordham International Law Journal, at 1478. 


\section{LEGALITY OF REQUIREMENTS IN THE BILATERAL INVESTMENT TREATY}

The majority of BITs established since 1995 only recognize investment from other parties if the investment complies with the host country's laws. ${ }^{13}$ This provision is called the admission clause. Provisions requiring investments to be made under the law are often included in investment agreements to ensure the investment's legality. ${ }^{14}$ Through this clause, the host country can implement a revenue and screening mechanism for foreign investment that may exist and hence determine the conditions under which foreign investment will be permitted to enter the country.

There are various variations of the admission clause used in the BIT agreement. An example of BIT Admission Clause can be seen in the Indonesia-United Kingdom BIT as stipulated in Article 2.1-Scope of Application states:

"This agreement shall only apply to investment by the nationals or companies of the United

Kingdom in the territory of the Republic of Indonesia which has been granted admission following the Foreign Capital Investment Law No.l of 1967 or any law amending or replacing it."

The other examples of variations of the admission clause stipulated in the BIT are as follows: ${ }^{15}$

\begin{tabular}{|c|c|c|}
\hline $\begin{array}{l}\text { BIT between Ethiopia and } \\
\text { the Russian Federation } \\
\qquad(2000)\end{array}$ & $\begin{array}{l}\text { BIT between Bahrain and } \\
\text { Thailand (2002) }\end{array}$ & $\begin{array}{l}\text { BIT between Australia } \\
\text { and Egypt (2001) }\end{array}$ \\
\hline $\begin{array}{l}\text { "Article 2.l. Promotion } \\
\text { and Protection of } \\
\text { Investments } \\
\text { 1. Each Contracting Party } \\
\text { shall encourage and } \\
\text { create favorable } \\
\text { conditions for Investors } \\
\text { of the other Contracting } \\
\text { Party to invest in its } \\
\text { territory and admit such } \\
\text { investments under its } \\
\text { laws and regulations." }\end{array}$ & $\begin{array}{l}\text { "Article 2. Scope of Application } \\
\text { 1. The benefits of this agreement } \\
\text { shall apply to the investments } \\
\text { by the investors of one } \\
\text { Contracting Party in the } \\
\text { territory of the other } \\
\text { Contracting Party, which is } \\
\text { specifically approved in } \\
\text { writing by the competent } \\
\text { authority under the laws and } \\
\text { regulations of the latter } \\
\text { Contracting Party." }\end{array}$ & $\begin{array}{l}\text { "Article } 3 \text { Promotion and } \\
\text { protection of investments } \\
\text { d. Each party shall } \\
\text { encourage and } \\
\text { promote investments } \\
\text { in its territory by } \\
\text { investors of the other } \\
\text { party and shall, under } \\
\text { its laws and } \\
\text { investment policies } \\
\text { applicable from time } \\
\text { to time, admit } \\
\text { investments." }\end{array}$ \\
\hline
\end{tabular}

A BIT agreement that contains an admission clause explicitly requires that only investments under the law of the host country fall under the jurisdiction of the court,

13 United Nations Conference On Trade And Development (UNCTAD). Bilateral Investment Treaties 19952006: Trends In Investment Rulemaking. (Geneva: UNCTAD, 2007) at 21.

14 Rahim Moloo \& Alex Khachaturian, supra note 12 at 1476.

15 UNCTAD, supra note 13. 
which decides the claim based on the BIT agreement. ${ }^{16}$ The obligation to follow the provisions stipulated in the national law of the host country is related to the legality of investments made by investors. Basically, the admission clause in the BIT that requires investments to be made under the law is often included to ensure the legality of the investment, thereby limiting approval for arbitration for disputes that meet their specific characteristics. ${ }^{17}$

A rule that arises from several investment treaty cases is that if the investment has been obtained by a foreign investor who violates the laws of the host country and the result of the action is to cause the investment becomes illegal; then the court does not have jurisdiction to adjudicate the claim of a foreign investor in arbitration. ${ }^{18}$ Following this approach, the validity of investment acquisitions is a condition that becomes a precedent for the transfer of adjudicative powers of investment agreements to the court. ${ }^{19}$

\section{THE ISDS MECHANISM IN THE BIT ON THE DISPUTE ARISING FROM UNLAWFUL ACTIONS BY THE INVESTOR}

\section{A. The Impact of Violations of the National Law of the Host State on} the Admission Clause in the BIT

The first case regarding the application of the ISDS mechanism on the unlawful actions by the investor in this study is the case between Inceysa Vallisoletana, S.L (Inceysa) against the Republic of El Salvador (El Salvador). In this case, Inceysa, as the claimant, filed a lawsuit against El Salvador for his actions, namely the breach of the contract, and the contract took over, which previously belonged to Inceysa. ${ }^{20}$ Inceysa got the contract on October 24, 2000, together with Ingenieria, Construccion y Arquitectura del Sur, S.A (INCASUR) after conducting a tender with the Ministry of Environment and Nature of El Salvador (MARN) together with four other companies. ${ }^{21}$ Inceysa and MARN signed the Inceysa Contract on November 17, 2000. Subsequently, on November 27, 2007 , Inceysa submitted a guarantee of implementation to MARN as stipulated in the contract.

After several problems arose between the parties, on 5 November 2001, Inceysa sent a letter to the Minister of MARN, in which he referred to the Agreement for the Promotion of Reciprocity and Investment Protection signed between the Kingdom of Spain and EI Salvador. On the 22nd and INCASUR jointly filed a complaint with MARN to ascertain whether the project would continue. On the same day, Inceysa sent a letter to the President of the Republic of El Salvador requesting intervention for the continuation of the project and asking for compensation for the two companies under

16 Christina Knahr, Investments "In Accordance With Host State Law," (2008) International Investment Law In Context 27 at 27

17 Rahim Moloo \& Alex Khachaturian, supra note 12.

18 Zacahry Douglas, The Plea of Illegality in Investment Treaty Arbitration, (2014) 29:1 ICSID Review, at 155.

19 Ibid.

20 Inceysa Vallisoletana, S.L. v. Republic of El Sal., ICSID Case No. ARB/03/26, Award, para at 3.

21 Ibid, para at 27. 
BIT. In July and August 2002, Inceysa complained to MARN about the breach of the contract because MARN recruited other companies to provide services that had been rented by Inceysa, thereby eliminating the exclusivity provided to it under the Inceysa Contract. ${ }^{22}$

In this case, El Salvador filed an objection to the ICSID jurisdiction. El Salvador's argument essentially states that their agreement to the ICSID jurisdiction was limited to disputes arising from investments protected by the Spanish-El Salvador BIT. According to El Salvador, the agreement of the parties (Spanish-El Salvador) in ICSID jurisdiction, which is stated in the Spanish-El Salvador BIT, is granted only for disputes related to investments made following Salvadoran EI law. ${ }^{23}$ The dispute between the Inceysa and El Salvador regarding is called jurisdiction rationa voluntatis.

The court found the parties' intention in the Spanish-El Salvador BIT was to exclude the investments that were not carried out under the legal provisions of the host country from the BIT scope of application and protection. In this case, the court considered that the desires between El Salvador and Spain could be seen through the minutes of treaty negotiations (travaux préparatoires) conducted several days before the agreement's entry into force. ${ }^{24}$ The Spanish-El Salvador BIT also has a reasonably strict admission clause as stipulated in Article 2, which states:

"... will also apply to investments made before it entered into force by the investors of a Contracting

Party under the laws of the other Contracting Partyin the territory of the latter..."

Furthermore, similar provisions are also included in Article 3 entitled Protection, which the article states: "Each Contracting Party shall protect in its territory the investments made, under its legislation..."

After determining that investments protected by the Spanish-El Salvador BIT are investments made under the host country's provisions, the court determines whether investments made by Inceysa are carried out under El Salvador's provisions. In the El Salvador national law, BIT is a legal source that is recognized under Article 144 of the Salvadoran Political Constitution. This does not merely make each investment subject protected by BIT, but to determine whether the investment benefits from that protection, it is necessary to analyze whether the investment was made under the requirements imposed in the BIT.

The court further found that the Incesya had committed fraud in the bidding process for government contracts. As a result, the court decided that they did not have jurisdiction over the dispute because Inceysa's investment did not meet the BIT's legal requirements. The court ruled that BIT, as the applicable law in El Salvador, is the primary and special law that must be analyzed by this court to determine whether Inceysa investment is carried out under the country's legal system.

In rejecting the jurisdiction of the prosecutor's investment, the court found that the Inceysa had violated the principle of good faith, the principle of the nemo auditor

\footnotetext{
Ibid, para at 34 .

Ibid, para at 141.

4 Ibid, para at 192.
} 
propriam turpitudinem allegans (no one could benefit from his own guilt), international public policy, and prohibitions on enrichment that violated the law. ${ }^{25}$

In other cases, Fraport AG Frankfurt Airport Services Worldwide v. Republic of the Philippine, the court ruled that "BIT explicitly and repeatedly requires that investments, in order to be eligible for BIT protection, must comply with the laws of the host country..." 26 . This is covered in Article 1 paragraph (1) of the German-Philippine BIT, which states: "the term investment shall mean any kind of asset accepted under the respective laws and regulations of either Contracting State..."

Based on the arbitration process, the arbitral panel found that the claimant (Fraport) consciously and deliberately avoided the Anti-Dummy Law - a domestic law that limits the ability of foreign investors to interfere in the management, operation, administration, or control of Philippine public facilities. Consequently, the plaintiff cannot claim to have made investments under the law, and the arbitral tribunal's decision decides that the arbitral tribunal does not have jurisdiction so that the lawsuit from Fraport is declared rejected. ${ }^{27}$

Based on the two cases, it can be seen that if the BIT agreement requires investment to be carried out under the laws of the host country, the parties in the BIT have decided that only investments made under the law of the host country are protected by BIT. There are issues regarding the scope of such clauses that cannot be generalized and can only be determined based on the investment agreement's specific wording. For example, most investment agreements only require investments to comply with the host country's laws when making investments. Certain investment agreements only require compliance with capital host country laws that govern investment receipts. ${ }^{28}$ Thus, the court must determine whether an investment must be carried out under the laws of the host country of capital to find out the court's jurisdiction over an investment claim.

The ISDS mechanism stated in the BIT in cases where there is an action against the national law of the host country is different in each case. In some cases, the ISDS mechanism can still be used, so investors can still use international investment arbitration as a reference in the BIT, but in some other cases, investors lose their right to use the ISDS mechanism. This difference is due to the different approaches taken by each arbitral tribunal. There is an arbitral tribunal that approaches the BIT interpreting strictly, and there is also an arbitral tribunal which interprets the BIT by considering other sources of law in international law. This is influenced by the scope of the admission clause contained in the BIT.

Cases where there is a violation of the national law of the host country by investors, but the investors can still benefit the ISDS mechanism in BIT can refer to the case of Churchill Mining Plc vs. the Government of Indonesia. Churchill vs. Indonesia case is

25 Ibid, para at 240-257.

26 Fraport AG Frankfurt Airport Services Worldwide v. the Republic of the Philippine. ICSID Case ARB/03/25, Award, para at 398.

27 Ibid, para 401.

28 Rahim Moloo \& Alex Khachaturian, supra note 12 at 1482. 
tried under the Indonesia-United Kingdom BIT. This case arises from the revocation of the Churchill mining licenses by the Indonesian Government because the Indonesian Government considers that Churchill falsified these licenses. ${ }^{29}$ Indonesia raised two objections to ICSID's authority in adjudicating disputes. In the first objection, Indonesia basically argued that Article 7 (1) of the British-Indonesian BIT did not consent for ICSID arbitration in connection with Churchill's claim. ${ }^{30}$ The second objection of Indonesia, in this case, is the legality of investment, which should not fall within the scope of the Indonesian-British BIT protection. ${ }^{31}$

In this case, it can be seen in the admission clause of the Indonesian-United Kingdom BIT as follows:

"This Agreement shall be only for investments by national or companies of the United Kingdom in the territory of the Republic of Indonesia which has been granted admission under the Foreign Capital Investment Law No. 1 of 1967 or any law amending or replacing it."

In this case, Indonesia argued that Churchill should not have received BIT protection because it did not get an entry permit under the Foreign Investment Law No. $1 / 1961$ or the law that replaced it. ${ }^{32}$ Indonesia believes that the admitted investments clause limits the scope of investment covered by BIT, even though the court found that Indonesia had given its consent to the ICSID Arbitration. Based on the Indonesia-United Kingdom BIT admission clause, it can be seen that the requirements for investment to be included in the protection provided by the Indonesia-United Kingdom BIT are accepted under the Foreign Investment Law No. 1/1961 or other laws that replace it. Because the current Foreign Investment Law No. 1/1961 has been replaced with the Investment Law No. 25/2007, the conditions for acceptance can be seen in the newer law.

The basic conditions of foreign investment in Indonesia, as stipulated in Article 5 paragraph (2) Investment Law No. 25/2007, are mandatory in the form of limited liability companies under Indonesian law and domiciled within the Republic of Indonesia territory unless otherwise stipulated by law. Before establishing a limited liability company, foreign investors must first pay attention to the business line to be carried out by the company included in the Indonesia Negative Investment List. This is regulated in Presidential Regulation No. 44 of 2016 concerning List of Closed Business Sectors and Open Business Sectors (Perpres No. 44 of 2016). Limited ownership of the company by foreign investors also has a maximum limit. Each line of business has a regulation regarding the maximum foreign ownership of each share. This is also regulated in Perpres No, 44 of 2016. After these requirements are met, only then can a limited liability company be established under general provisions. After that, foreign investors have to take care of foreign company licensing, namely making business licenses and other permits from the Investment Coordinating Board (BKPM) and other relevant agencies.

\footnotetext{
${ }^{29}$ Huala Adolf, Sengketa Penanaman Modal Antara Investor Melawan Pemerintah Indonesia di Arbitrase ICSID, (2014) 1:3 Padjadjaran Jurnal Ilmu Hukum, at 437.

${ }^{30}$ Churchill Mining Plcv. the Republic OfIndonesia, ICSID Case No. ARB/12/14 And 12/40, Decisions on Jurisdiction, Para at 97.

31 Ibid, Para at 240.

32 Ibid, Para at 241.
} 
After obtaining the permit, referring to Article 2 paragraph 1 of the Indonesian-United Kingdom BIT, it can be said that the investment made by the foreign investor from the United Kingdom has been protected by the Indonesian-United Kingdom BIT.

It can be concluded that the admission clause in the Indonesia-United Kingdom BIT has a narrow scope because it only requires investment to be recognized under the laws governing investment. Moreover, the Foreign Investment Law does not specify procedures for foreign investors to obtain government approval, as referred to in Article 2 (1) of the Indonesia-United Kingdom BIT, nor does it appoint an authority responsible for applying the law.

The narrow scope of the Indonesian-United Kingdom BIT Admission Clause has an impact on the Churchill vs. Indonesia case. In this case, the parties agree that BKPM is the authority responsible for giving investment approval, as referred to in Article 2(1) of the Indonesia-United Kingdom BIT. On this basis, the Churchill vs. Indonesia arbitral tribunal concluded that Churchill obtained the necessary approval when investing in May 2006, so that it met the requirements specified in Article 2 paragraph(1) of the Indonesia-United Kingdom BIT. In this case, the arbitral tribunal also stated that the scope of the Indonesia-United Kingdom BIT Admission Clause was narrower than the Admission Clause contained in the BIT in general because it only required the entry of investments. Due to having fulfilled the requirements specified in Article 2 paragraph (1) of the BIT, the Arbitration Tribunal decided that Churchill's investment had the right to enter the scope of protection of the Indonesian-United Kingdom BIT and the arbitral tribunal had jurisdiction to adjudicate the dispute. ${ }^{33}$

It can be concluded that the scope of the admission clause in the BIT has a position that is closely related to the implementation of the ISDS mechanism. The scope of the admission clause determines whether an investment is covered by the BIT protection or otherwise. The narrow scope of the admission clause, such as the Indonesian-British BIT, facilitates investment in obtaining the benefits provided by BIT, while the broad scope of admission will tighten the requirements of investment to obtain BIT protection. When an investment does not meet the requirements specified by the BIT's admission clause, then the investment made by the investor is not protected by the BIT. Therefore, for investments where there is a violation of the national law of the host country by the investor, the BIT's rights, including the ISDS mechanism, cannot be applied to investors in such conditions.

\section{B. The Impact of The Violations of the Admission Clause on the ICSID Jurisdiction}

ICSID's jurisdiction over a claim submitted to them is governed by Article 25 of the ICSID Convention. Article 25 The ICSID Convention is the basis for the ICSID arbitral tribunal to determine whether the arbitral tribunal has the right to hear a claim from the plaintiff or not. The lack of fulfillment of these jurisdictional conditions means that the court does not have the competence to adjudicate the disputes. ${ }^{34}$ The basis for the

\footnotetext{
33 Ibid, Para at 313.

34 Rahim Moloo \& Alex Khachaturian, supra note 14.
} 
authority to have jurisdiction on the dispute can be found in a direct agreement between the parties, the national law of the host country, and bilateral or multilateral agreement between the host country and the country of origin..$^{35}$

The link between actions against the national law of the host country by the investor and the ICSID's jurisdiction is related to the rationa voluntatis and rationa materiae as basic ICSID jurisdiction requirements. Before parties give authority to ICSID to adjudicate a dispute, there must be an agreement in advance between the parties. ${ }^{36}$ The ICSID tribunal has rationa voluntatis, after stipulating that the parties have agreed to settle the dispute by arbitration. ${ }^{37}$ The arbitral tribunal will assess the basis for the authority to adjudicate submitted by the plaintiff in his lawsuit to assess the parties' agreement to settle the dispute through arbitration. If the arbitral tribunal considers that the dispute is outside the agreement parties' agreement, the arbitral tribunal's decision is likely to reject the claim from the plaintiff.

In the case of Incesya vs. El Salvador, one of the objections of El Salvador, was refusing to give ICSID approval to adjudicate a dispute submitted by Inceysa based on the BIT. Approval of the jurisdiction of the ICSID is only granted by the Spanish-El Salvador BIT for investments made in compliance with the laws of the host country of capital, which in this case, is the national law of El Salvador. By not fulfilling these requirements, El Salvador considers that the Inceysa dispute did not get approval from El Salvador to be resolved through an arbitration mechanism in BIT.

The arbitral tribunal which adjudicated the dispute of Inceysa and El Salvador considers that its fundamental obligation is to identify the issues, including the consent granted by El Salvador. ${ }^{38}$ In addition, the ICSID panel also noted that the examination of the consent disclosed by the parties was a mandatory stage of any court. As previously explained, the arbitral tribunal that tried the Inceysa case decided that the Spanish-El Salvador BIT did not protect unlawful investments. Furthermore, the arbitral tribunal stated that the act would implicitly give the state the right to unilaterally revoke the agreement by determining the legality of investment based on their law.

Besides being related to rationa voluntatis, the act that violates the national law of the host country is also often related to rationa materiae or the dispute's object. Rationa materiae means that there should be the jurisdiction of the court to issue the subject of dispute. ${ }^{39}$ The basis of rationa matierae stipulated in Article 25 of the ICSID Convention, which states that ICSID has the authority to adjudicate all disputes arising from investment (any legal dispute arising directly from an investment). In general practice of investment arbitration, the investments that violate the national law of the host country are often considered not to meet the investment definition in the BIT. In various BITs, some states the obligation to fulfill the national law of the host country of the capital

35 R. Dolzer \& M. Stevens. Bilateral Investment Treaties. (The Hague: M. Nijhoff, 1995) at 228-229.

36 Huala Adolf. Hukum Penyelesaian Sengketa Penanaman Modal. (Bandung: CV Keni Media, 2011) at 54.

37 Christopher F Dugan, et al. Investor-State Arbitration. (New York: Oxford University Press, 2011) at 219.

38 Inceysa Vallisoletana, S.L. v. Republic of El Sal., supra note 20 para at 170.

39 M. Sornarajah. International Investment Law. (United Kingdom: Cambridge University Press, 2004) at 306. 
required in the definition of investment in a BIT or multilateral agreement. This can be seen in the German-Philippine BIT as follows:

"The term investment shall mean any kind of asset accepted under the respective laws and regulations of either Contracting State..."

Basically, this form of BIT is another form of the admission clause wherein arbitration is known as an investment legality requirement. When referring to the case of Fraport vs. the Philippines, where the case is under the German-Philippine BIT, the tribunal which hears the case considers that the definition of investment in the BIT is a lex specialis of Article 25 of the ICSID Convention. Therefore, due to the non-fulfillment of these requirements, the investment made by Fraport does not meet the definition set by the German-Philippine BIT. Then, the arbitration panel handling this case decided that ICSID did not have the authority to adjudicate it. ${ }^{40}$

Accordingly, it can be concluded that if the legality requirements in the BIT are not explicitly regulated, then the case of violation of the national law of the recipient country committed by investors is not related to the authority to judge from ICSID as stipulated in Article 25 of the ICSID Convention. Although the violation of the national law of the host country, in this case, is not related to the authority to prosecute the ICSID, the law's violation can still be related to the protection of investment, which in this case concerns the application of standards of protection in the BIT.

\section{THE APPLICATION OF STANDARDS OF PROTECTION ON THE UNLAWFUL ACTIONS BY THE INVESTOR}

\section{A. The Linkage of Violations of National Law of the Host Country to Violations of General Principles of International Law}

The obligation to follow the provisions of general principles of international law affects the protection provided in BIT or multilateral investment agreements. ${ }^{41}$ Referring to the Incesya case, it can be seen that actions violating the national law of the host country by investors impact the violation of the general principles of international law. Violations of the national law of the host country impact the general principles of international law, among others, the violation of the principle of good faith, the principle of nemo auditors propiam turpitudinem allegans, and the international public policy, and the principle prohibiting unlawful enrichment. The violation is one of the grounds for rejecting a lawsuit filed by Incesya because investments made by Incesya in violation of El Salvador's national law are deemed not entitled to international legal protection.

By taking into account the verdict issued by the arbitration panel Incesya vs. El Salvador, the application of violations of the principles of general international law, is actually not appropriate when applied in the rejection of the authority to adjudicate a dispute. This is because there is no clear link between the violation of general principles

40 Fraport AG Frankfurt Airport Services Worldwide v Republic of the Philippines, supra note 26 para at 305.

41 Rahim Moloo \& Alex Khachaturian, supra note 12 at 1474. 
of international law with the terms of the authority to try the ICSID as regulated in Article 25 of the ICSID Convention. The application of general principles of international law in disputes arising from violations of national laws of the host country is more appropriate to be applied in the primary process of determining the admissibility of claims or merits of the claim as applied in the Churchill vs. Indonesia case. This application aims to see whether investments made by investors are entitled to protection.

Violations of other general principles of international law relating to violations of the host country's national law can be seen in consideration of the arbitral tribunal which hears the Churchill vs. Indonesia case. In its consideration, the arbitral tribunal linked Churchill's actions to cases that had already existed. This is because both the ICSID Convention and the BIT do not contain substantive provisions that discuss the consequences of unlawful behavior. BIT only contains acceptance requirements that apply at the time of the establishment of an investment, which is jurisdictional. Therefore, the Churchill arbitration tribunal vs. Indonesia refers to the general principles of international law to determine the consequences of Churchill's fraud. ${ }^{42}$

There are several cases described by the decision of the Churchill vs. Indonesia arbitral tribunal, which states that there is a link between the violation of the national law of the host country and the violation of general principles of international law. One case is the case of Venezuela Holdings vs. Venezuela. The case stated that the entire legal system, including the international legal system, some principles prevent abuse of law. ${ }^{43}$ More specifically, it was explained to the arbitral tribunal of the Phoenix vs. the Czech Republic case that the arbitral panel was tasked with protecting the misuse of the system from the protection of international investment under the ICSID or BIT Convention. ${ }^{44}$ Another case described by the arbitral tribunal relating to violations of the national law of the host country with violations of general principles of international law is the Hamester vs. Ghana case which states that fraud is a violation of the principle of good faith which is also an abuse of rights and abuse of process.

By revisiting the case of Incesya vs. El Salvador and Indonesia vs. Churchill, the application of general principles of international law in determining protection for investment, is because the BIT, which is the basis for protecting the investment, is based on the national law of the state parties and the general principles of international law. Moreover, there are generally no legal consequences for violations of the law committed by investors in BIT. Therefore, the principles of international law and the protection provided to investors have a very close relationship in determining the protection that can be given to investments, impacting the application of standards of protection to investors.

42 Churchill Mining Plc and Planet Mining Pty Ltd v. the Republic Of Indonesia, ICSID Case No. ARB/12/14 And 12/40, Awards, Para at 487.

43 Venezuela Holdings B.V. and others v. the Bolivarian Republic of Venezuela, ICSID Case No. ARB/07/27, Decision on Jurisdiction, 10 June 2010, para at 167.

44 Phoenix Action, Ltd. v. the Czech Republic, ICSID Case No. ARB/06/5, Award, 15 April 2009, para at 144. 


\section{B. The Impact of Violating National Laws of Host Countries on the Implementation of Standards of Protection}

The interpretation of investment agreements (BIT or multilateral investment agreements) cannot be separated from the general principles of international law. Adherence to international law principles is one of the factors that determine whether an investment is entitled to protection from international law. This is because to assess an investment has the right to get protection from BIT or not, it must be seen in general whether the investment is entitled to protection under international law or not.

The legal consequences of fraud committed by investors largely depend on the circumstances of each case. They include the applicable agreement, the seriousness of the violation, the role of the disputing party or third party to the violation, the relationship between the violation and the claim, and the time when the violation. Cases of severe law violations, such as corruption, have been deemed contrary to international public policy. The common law doctrine about unclean hands that prohibits claims made under illegal actions is also found on an international level. ${ }^{45}$

In the Hamester vs. Ghana case, as described in the Churchill vs. Indonesia case, no protection can be given to investments made in violation of the principles of good faith in national law or international law. This is stated as follows:

"An investment will not be protected if it has been created in violation of national or international principles of good faith; by way of corruption, fraud, or deceitful conduct; or if its creation itself constitutes a misuse of the system of international investment protection under the ICSID Convention. It will also not be protected if it is made in violation of the host state's law."

Also emphasized in the case of Minnote vs. Poland, apart from the absence of legality requirements listed in the BIT, it is now generally accepted that investments made based on fraudulent actions cannot benefit from BIT protection. The Churchill vs. Indonesia arbitral tribunal in its decision stated that as a result of fraud committed by Churchill, referring to the principle of good faith and prohibition of misuse of the process, claims filed by Churchill cannot benefit from investment protection under Indonesian BIT and, therefore, claims which submitted by Churchill was deemed unacceptable.

One of the cases described by the arbitral tribunal in the dispute between Churchill and Indonesia was the Hamester vs. Ghana case. In this case, the arbitral tribunal which tried the case stated that no protection could be given to investments made in violation of the principles of good faith in national law or international law. This is stated as follows:

"An investment will not be protected if it has been created in violation of national or international principles of good faith; by way of corruption, fraud, or deceitful conduct; or if its creation itself constitutes a misuse of the system of international investment protection under the ICSID Convention. It will also not be protected if it is made in violation of the host state's law."

45 Churchill Mining Plc and Planet Mining Pty Ltd v. the Republic of Indonesia, ICSID Case No. ARB/12/14 and 12/40, Awards, Para at 493. 
Referring to the description of the case above, the impact of violating the national law of the host country of capital causes investments made in violation of the national law of the host country of capital not to get international legal protection. This directly impacts the application of standards of protection where investments made in violation of the host country's national law cannot obtain the standards of protection provided in the BIT or, in general, based on the custom of international law. Basically, the international legal system prevents protection to those who are not entitled to protection. Therefore, the violation of the national law of the host country of capital has a significant impact on investors' investment protection.

The application of standards of protection in cases where investors have proven violations of the host country's national law tends to be more uniform than the application of the ISDS mechanism in cases arising from violations of the national law of the host country. The main factor that determines this is because determining the application of the standards of protection of the law used is the same, namely from the general principles of international law, in contrast to determining the position of the ISDS mechanism which must first look at the requirements specified in the BIT where each BIT has a different scope of requirements.

\section{CONCLUSION}

The position of the ISDS mechanism in BIT for investments made in violation of the host country's national law has different applications in each case. In the Churchill vs. Indonesia case, ICSID has the authority to adjudicate the case because the acceptance requirements in the Indonesia-United Kingdom BIT are limited to investment formation. In the case of Incesya vs. El Salvador, ICSID refused the authority to try it because there were specific rules required in the Spanish-El Salvador BIT so that investment would be protected in the BIT. It can be seen through the two cases that the main cause of the difference is the scope of the admission clause or the acceptance requirements in the BIT that vary in each BIT. The difference in scope determines whether BIT can be used as the basis for the authority to judge from ICSID. This is because, in Article 25, the ICSID Convention requires that disputes originate from investment activities (rationa materiae), and there is approval from the state of the authority to prosecute ICSID (rationa voluntatis). In this case, the author agrees that actions that violate national law of the host country are not entitled to the slightest protection under international law. Therefore, the ISDS mechanism and standards of protection should not be applied in these conditions because it would contradict with the general principles of international law.

The Indonesian government must be firm in implementing the ISDS mechanism in every investment dispute that will arise. The government can review the acceptance requirements contained in the BIT conducted by Indonesia with other countries. This is because, at this time, the acceptance requirements specified in the BIT made by Indonesia are still too narrow, so that it will allow investors to quickly get the benefits provided by BIT, one of which is the ISDS mechanism. In the event of a violation of 
national law by the investor, the investor's right will be lost for protection in Indonesia because it would conflict with some general legal principles in international law.

The application of standards of protection to investments that have been proven to violate the host country's national law tends to have the same application in each case. In the case of Churchill vs. Indonesia, the arbitral tribunal rejected the lawsuit filed by Churchill. It stated that Churchill was not entitled to any protection under international law because Churchill had committed fraud in his investment, violating the principle of good faith and prohibiting the abuse of the arbitration process. The arbitral tribunal also refers to several similar cases and links them to the general principles of international law. Equality of legal consequences for the actions of investors who violate the national law of the host country because in general, the BIT does not clearly regulate the consequences of violating the national law of the host country by the investor so that the arbitration panel will refer to the general principles of international law.

At present, generally, the BITs made by Indonesia have not included the legal consequences of violating Indonesian national law. These consequences must be reiterated in the BIT to illustrate investors if they violate Indonesian national law. Therefore, the Indonesian government that already has a BIT with a new model to be able to pay attention to the previous BIT or MIT that currently exists in particular adds provisions on how the impact of violations of Indonesian national law on the protection of BIT.

\section{ACKNOWLEDGMENTS}

None.

\section{COMPETING INTERESTS}

The authors declare that they have no competing interests.

\section{REFERENCES}

An An Chandrawulan. Peran dan Dampak Perusahaan Multinasional dalam Pembangunan Ekonomi Indonesia Melalui Penanaman Modal dan Perdagangan Internasional. (Bandung: Fikahati Aneska, 2012).

Christina Knahr. Investments "In Accordance With Host State Law". (2008) International Investment Law In Context 27.

Christopher F. Dugan. Investor-State Arbitration. (New York: Oxford University Press, 2011).

Churchill Mining PLC and Planet Mining Pty Ltd v. the Republic of Indonesia, ICSID Case No. ARB/12/14 And 12/40, Awards.

Churchill Mining PLC V Republic of Indonesia, ICSID Case No. ARB/12/14 And 12/40, Decision on Jurisdiction 
David Minnotte and Robert Lewis v. the Republic of Poland, ICSID Case No. ARB(AF)/10/1, Award, 16 May 2014.

Fraport AG Frankfurt Airport Services Worldwide v. the Republic of the Philippine.

ICSID Case ARB/03/25, Awards.

Fredy Roeroe, et al. Batam Komitmen Setengah Hati. (Jakarta: Aksara Karunia, 2003).

Gustav F W Hamester GmbH \& Co KG v. the Republic of Ghana, ICSID Case No. ARB/07/24, Award, 18 Juni 2010.

H. H. Koh. Why Do Nations Obey International Law?. (1997) Faculty Scholarship Series Paper 2101, Yale Law School Legal Scholarship Repository.

Huala Adolf. Hukum Penyelesaian Sengketa Penanaman Modal. (Bandung: CV Keni Media, 2011).

Huala Adolf. Perjanjian Penanaman Modal Dalam Hukum Perdagangan Internasional (WTO). (Bandung: Rajagrafindo, 2004).

Huala Adolf. Sengketa Penanaman Modal Antara Investor Melawan Pemerintah Indonesia Di Arbitrase ICSID. (2014) 1:3 Padjadjaran Jurnal Ilmu Hukum.

Jeswald W. Salauce \& $\&$ Nicholas P. Sullivan. Do BITS Really Work?: An Evaluation Of Bilateral Investment Treaties And Their Grand Bargain. (2005) 46 Harvard International Law Journal 67.

Kusnowibowo. Hukum Investasi Internasional. (Bandung: Pustaka Reka Cipta, 2019).

M. Sornarajah. International Investment Law. (United Kingdom: Cambridge University Press, 2004).

Prita Amalia \& Danrivanto Budhijanto. The Force of Strategic Infrastructures: The Role of Public-Private-Partnership to Strengthen Sustainable Developments in Indonesia. (2018) 12:4 Central European Journal of International and Security Studies.

Rachmi Hertanti \& Rika Febriani. BIT (Bits) 'Negara VS Korporasi'. (Jakarta: Indonesia For Global Justice, 2014).

Rahim Moloo \& Alex Khachaturian. The Compliance With The Law Requirement In International Investment Law. (2011) 34:6 Fordham International Law Journal.

Rudolf Dolzer \& Christoph Schreur. Principles of International Investment Law. (New York: Oxford University Press, 2008).

United Nations Conference on Trade and Development (UNCTAD). Bilateral Investment Treaties 1995-2006: Trends In Investment Rulemaking. (Geneva: UNCTAD, 2007).

United Nations Conference on Trade and Development. Investor-State Dispute Settlement. (UNCTAD Series on Issues in International Investment Agreements II, 2014).

Venezuela Holdings B.V. and others v. the Bolivarian Republic of Venezuela, ICSID Case No. ARB/07/27, Decision on Jurisdiction, 10 June 2010, para. 167.

Wachid Aditya Ansory, et al. The Application of the MFN Principle to the 'Over Top' Companies in Investment Activities of Indonesia. (2019) 6:2 Lentera Hukum.

Zacahry Douglas. The Plea Of Illegality In Investment Treaty Arbitration. (2014) 29:1 ICSID Review. 
170 | The ISDS Mechanism and Standards of Protection in the Investment Treaty

This page is intentionally left blank 